\title{
Human rhinovirus in the lower respiratory tract infections of young children and the possible involvement of a secondary respiratory viral agent
}

\author{
Nayhanne Tizzo de Paula ${ }^{1}$, Bruno Moreira Carneiro', Jonny Yokosawa ${ }^{1}{ }^{+}$, \\ Guilherme Ramos Oliveira e Freitas ${ }^{1}$, Thelma Fátima de Mattos Oliveira1, \\ Lourenço Faria Costa1, Hélio Lopes da Silveira ${ }^{1,2}$, Divina Aparecida Oliveira Queiróz ${ }^{1}$
}

'Laboratório de Virologia, Instituto de Ciências Biomédicas Faculdade de Medicina, Universidade Federal de Uberlândia, Av. Pará 1720 Bl. 4C, 38400-902 Uberlândia, MG, Brasil

\begin{abstract}
Human rhinoviruses $(H R V)$ are usually associated with mild respiratory symptoms in children. However, some studies have found that HRV can cause severe disease, especially when the patient is co-infected with a second virus. In this study, 532 nasopharyngeal aspirates (NPAs) were collected over a nine-year period from children at the Clinics Hospital of Uberlândia. The collected NPAs were then tested for HRV RNA using the reverse transcriptionpolymerase chain reaction. Eighty-three specimens from children diagnosed with lower respiratory tract illness (LRTI) were positive for HRV RNA and were then tested for the presence of eight other respiratory viruses. A second virus was detected in $37.3 \%$ (31/83) of the samples. The most frequent clinical diagnosis was bronchiolitis, followed by other LRTI and then pneumonia. The frequency of severe disease in children infected with more than one virus was not significantly different from the frequency of severe disease in children infected with HRV alone. Children infected with both HRV and parainfluenza virus (1.5 m.o.) were significantly younger than those infected by HRV alone $(5.0$ m.o.) $(p=0.0454)$. Overall, these results suggest that infection with a second virus does not lead to a higher frequency of severe syndromes in children presenting with LRTI.
\end{abstract}

Key words: human rhinoviruses - co-infection - lower respiratory tract - young children

Human rhinovirus (HRV) is typically associated with mild upper respiratory tract infections and exacerbation of asthma in children (Gern \& Busse 1999, Manoha et al. 2007, Mackay 2008, Kelly \& Busse 2008). HRV is a member of the Picornaviridae family and is composed of a nonenveloped particle with a positive-sense single-stranded RNA genome. The genome consists of 11 genes that are translated as a single polyprotein, which is divided into three regions (P1, P2 and P3) that are subsequently cleaved into four mature structural (VP4, VP2, VP3 and VP1) and seven non-structural proteins $\left(2 \mathrm{~A}, 2 \mathrm{~B}, 2 \mathrm{C}, 3 \mathrm{~A}, 3 \mathrm{~B}, 3 \mathrm{C}^{\mathrm{PRO}}\right.$ and $3 \mathrm{D}^{\mathrm{POL}}$ ) (Kirchberger et al. 2007, Kistler et al. 2007, Mackay 2008). Three HRV species have been described: A, B and C (Lau et al. 2007, Palmenberg et al. 2009).

Previously, diagnosis of HRV was difficult because culture of the virus was limited (Cheuk et al. 2007, Paranhos-Baccalà et al. 2008). Due to advances in nucleic acid amplification, we can now detect HRV and determine when HRV is the causative agent of lower respiratory tract illness (LRTI) (Choi et al. 2006, Miller et al. 2007, Gerna et al. 2009, Louie et al. 2009). HRV is fre-

Financial support: CAPES, CNPq, FAPEMIG

+ Corresponding author: jyokosawa@icbim.ufu.br

Received 5 October 2010

Accepted 23 March 2011 quently detected in children diagnosed with bronchiolitis and pneumonia (Manoha et al. 2007, Miller et al. 2007, Louie et al. 2009). Additionally, HRV can cause severe complications in patients that are immunocompromised (Malcolm et al. 2001) or have underlying chronic disorders (Kim \& Hodinka 1998, Glezen et al. 2000, Cheuk et al. 2007, Dreschers et al. 2007).

Identification of HRV co-infection with other respiratory viruses, such as respiratory syncytial virus (RSV) (Papadopoulos et al. 2002, Miller et al. 2007, ParanhosBaccalà et al. 2008, Marguet et al. 2009), is possible because of advances in the molecular detection of HRV (Aberle et al. 2005, Jacques et al. 2006, Calvo et al. 2008). Scientists have questioned whether or not HRV co-infections lead to more severe clinical syndromes, cause longer hospitalisations and affect younger children more frequently (Drews et al. 1997, Papadopoulos et al. 2002, Calvo et al. 2007, 2008, Richard et al. 2008, Gerna et al. 2009, Midulla et al. 2010).

The objective of this study was to identify cases of HRV co-infection in nasopharyngeal aspirates (NPAs) from children presenting with LRTI and to determine if there is an association between viral co-infection and the clinical severity of bronchiolitis, pneumonia and LRTI.

\section{PATIENTS, MATERIALS AND METHODS}

Patients and clinical specimens - From 2000-2009, a total of 552 NPAs were collected from children presenting with symptoms of acute respiratory disease (ARD) at the Clinics Hospital of Uberlândia, Federal University of Uberlândia (HCU-UFU) in the state of Minas Gerais, 
Brazil. Patients included in the study were less than five years of age and were admitted to the hospital within five days of the onset of ARD symptoms. The HCU-UFU is a public university hospital that provides health care to students and low-income individuals living in Uberlândia, as well as 120 other cities and towns in the region, covering an estimated population of two million people. This study was approved by UFU's ethics committee according to registration $387 / 08$. Informed consent was obtained from each child's parent.

As part of the surveillance for respiratory viruses, samples are routinely screened using an indirect immunofluorescence assay that can detect seven common respiratory viruses [respiratory syncytial virus, influenzaviruses (FLU) A and B and parainfluenza viruses (PIV) 1, 2, 3 and adenovirus].

Detection of $H R V$ - Samples that were negative or inconclusive in the initial screening (321 samples) were screened for HRV RNA using the reverse transcriptionpolymerase chain reaction (RT-PCR). RNA was extracted with Trizol ${ }^{\circledR}$ (Invitrogen Corp, Carlsbad, CA) according to the manufacturer's instructions. Complementary DNA (cDNA) was synthesised using the SuperScript ${ }^{\circledR}$ III Reverse Transcriptase mix and an HRV-specific primer according to the manufacturer's protocol. Briefly, $5 \mu \mathrm{L}$ of total RNA was mixed with 2 pmol of primer 1 (5'-GCACTTCTGTTTCCCC-3') and $10 \mathrm{mM}$ of dNTP mix and incubated at $65^{\circ} \mathrm{C}$ for $5 \mathrm{~min}$. Then, $4 \mu \mathrm{L}$ of buffer 5x FS, 0.1M DTT, 200 units of Superscript III and $20 \mu \mathrm{L}$ of water was added to the mix, which was then heated at $55^{\circ} \mathrm{C}$ for $1 \mathrm{~h}$. Following cDNA synthesis, the enzyme was heat inactivated at $70^{\circ} \mathrm{C}$ for $10 \mathrm{~min}$. Amplification of the HRV nucleotide sequence was performed as previously described by Costa et al. (2006). For the first-round of PCR, the cDNA template was amplified with primers 1 and 2 (5'-CGGACACCCAAAGTAG-3'). The amplification conditions used were as follows: $95^{\circ} \mathrm{C}$ for $1 \mathrm{~min}, 40$ cycles of $94^{\circ} \mathrm{C}$ for $1 \mathrm{~min}, 48^{\circ} \mathrm{C}$ for $1 \mathrm{~min}$ and $72^{\circ} \mathrm{C}$ for $1 \mathrm{~min}$ and a final step of $72^{\circ} \mathrm{C}$ for $5 \mathrm{~min}$. One microlitre of the first-round PCR product was used as the template for the second-round PCR with primers 3 (5'-AGCCTGCGTGGCTGCC-3') and 4 (5'-GCATTCAGGGGCCGGAG-3'). The second-round PCR amplification conditions were the same as the first-round except that 30 cycles were run instead of 40 .

Co-infection testing - Clinical specimens that were positive for HRV RNA and were collected from patients who presented with a clinical diagnosis of LRTI were selected for additional screening for eight respiratory viruses. Briefly, RSV A and B and FLU A and B were detected using multiplex two-step PCR reactions with previously described primers and conditions (Stockton et al. 1998). Human metapneumovirus (hMPV) was detected using a protocol that was previously described by our group (Carneiro et al. 2009). Finally, PIV 1-3 were detected using the primers and conditions published by Echevarría et al. (1998). Primer sequences, expected fragment lengths and viral primer targets are listed in Table I.

Due to the limited specimen volume, samples in which a second virus was detected were not tested for the presence of an unlikely triple infection. RSV A and
B and FLU A and B (Stockton et al. 1998) were the first viruses tested for, followed by hMPV (Carneiro et al. 2009) and PIV 1-3 (Echevarría et al. 1998). This order was chosen according to clinical relevance of co-infections in children as determined by the literature (Aberle et al. 2005, Calvo et al. 2008, Cilla et al. 2008, Richard et al. 2008) and because of the circulation rate of the most common viruses in the region (Costa et al. 2006).

Clinical criteria - Clinical syndromes were characterised as bronchiolitis, pneumonia or other LRTI (acute bronchitis, sibilant bronchitis, tracheobronchitis and croup). A responsible physician performed classification of clinical severity at the time of sample collection. Bronchiolitis was characterised as mild, moderate or severe according to the parameters defined by the "clinical score of respiratory failure in bronchiolitis" adapted by De Boeck et al. (1997). Pneumonia was classified as pneumonia, severe pneumonia or very severe pneumonia according to criteria defined by the World Health Organization (WHO 2005). Clinical scores adapted by Taussig et al. (1975) were used to classify the other LRTI syndrome clinical scores.

Statistical analysis - The data were analysed using Graphpad Prism 4.0 (GraphPad Software Inc San Diego, CA, USA). The evaluation of the median ages of different groups was performed using the Mann-Whitney $U$ test and Fisher's exact test was used to analyse the difference between clinical manifestations in children with either a single or dual viral infection.

\section{RESULTS}

Eighty-three patients diagnosed with LRTI had specimens that were positive by RT-PCR for HRV RNA. Coinfection with a second virus was found in $37.3 \%(31 / 83)$ (Table II) of the 83 specimens. RSV was detected as the second virus in $23 \%(19 / 83)$ of the specimens, followed by hMPV and PIV, which were both detected in 7\% $(6 / 83)$ of the specimens, and three cases each of PIV-1 and 2 were detected. FLU A and B and PIV-3 were not detected in these samples.

Regarding seasonality, Fig. 1 shows that from 20002009, HRV, RSV, hMPV and PIV co-circulate and that outbreaks occurred primarily between February-June (mid-summer to late autumn) with the highest incidence in April and May.

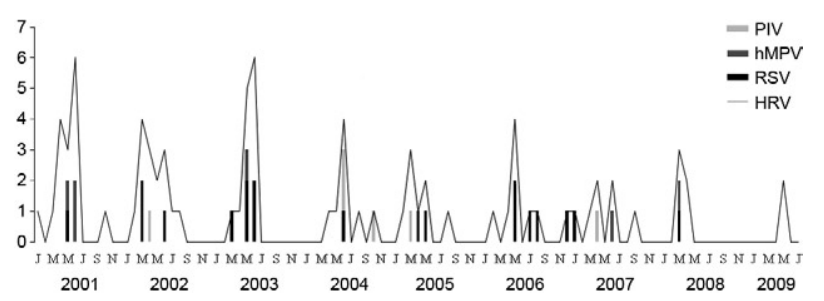

Fig. 1: seasonal distribution of viruses detected in children presenting lower respiratory tract illness. hMPV: metapneumovirus; HRV: human rhinovirus; PIV: parainfluenza viruses; RSV: respiratory syncytial virus. 
TABLE I

Properties of primers used in polymerase chain reaction (PCR) for human rhinovirus (HRV), respiratory syncytial virus (RSV), influenzavirus (FLU), human metapneumovirus (hMPV) and parainfluenza virus (PIV) detection

\begin{tabular}{|c|c|c|c|c|}
\hline Primers & Sequence (5'-3') & $\begin{array}{c}\text { Amplicon size } \\
\text { (primer's description) }\end{array}$ & $\begin{array}{l}\text { Target } \\
\text { gene }\end{array}$ & Virus detected \\
\hline $110822 \mathrm{~F}^{b}$ & GCACTTCTGTTTCCCC & \multirow{2}{*}{$\begin{array}{c}390 \text { bp } \\
\text { (Arruda \& Hayden 1993) }\end{array}$} & UTR & \multirow[t]{4}{*}{ HRV } \\
\hline $110823 \mathrm{R}^{b}$ & CGGACACCCAAAGTAG & & UTR & \\
\hline $110824 \mathrm{~F}^{a}$ & AGCCTGCGTGGCTGCC & \multirow{2}{*}{$\begin{array}{c}110 \text { bp } \\
\text { (Arruda \& Hayden 1993) }\end{array}$} & UTR & \\
\hline $110825 \mathrm{R}^{a}$ & GCATTCAGGGGCCGGAG & & UTR & \\
\hline $\mathrm{RSV} \mathrm{AB} \mathrm{F}^{b}$ & GTCTTACAGCCGTGATTAGG & \multirow{2}{*}{$\begin{array}{c}838 \text { bp } \\
\text { (Stockton et al. 1998) }\end{array}$} & $\mathrm{N}$ & \multirow[t]{6}{*}{ RSV A and B } \\
\hline RSV AB R ${ }^{b}$ & GGGCTTTCTTTGGTTACTTC & & $\mathrm{P}$ & \\
\hline RSV A F ${ }^{a}$ & GATGTTACGGTGGGGAGTCT & \multirow{2}{*}{$\begin{array}{c}334 \text { bp } \\
\text { (Stockton et al. 1998) }\end{array}$} & $\mathrm{N}$ & \\
\hline RSV A R ${ }^{a}$ & GTACACTGTAGTTAATCACA & & $\mathrm{N}$ & \\
\hline RSV B F ${ }^{a}$ & AATGCTAAGATGGGGAGTTC & \multirow{2}{*}{$\begin{array}{c}183 \text { bp } \\
\text { (Stockton et al. 1998) }\end{array}$} & $\mathrm{N}$ & \\
\hline RSV B R ${ }^{a}$ & GAAATTGAGTTAATGACAGC & & $\mathrm{N}$ & \\
\hline AHI A F ${ }^{b}$ & CAGATGCAGACACAATATGT & \multirow{2}{*}{$\begin{array}{c}1,015 \text { bp } \\
\text { (Ellis et al. 1997) }\end{array}$} & HA & \multirow[t]{12}{*}{ FLU A (H3 and $\mathrm{H} 1)$ and B } \\
\hline AHI FII R ${ }^{b}$ & AAACCGGCAATGGCTCCAAA & & HA & \\
\hline AH3 A F $^{b}$ & CAGATTGAAGTGACTAATGC & \multirow{2}{*}{$\begin{array}{c}883 \\
\text { (Ellis et al. 1997) }\end{array}$} & HA & \\
\hline AH3 DII R ${ }^{b}$ & GTTTCTCTGGTACATTCCGC & & HA & \\
\hline BHA A F ${ }^{b}$ & GTGACTGGTGTGATACCACT & \multirow{2}{*}{$\begin{array}{c}900 \mathrm{bp} \\
\text { (Ellis et al. 1997) }\end{array}$} & HA & \\
\hline BHA DII $\mathrm{R}^{b}$ & TGTTTTCACCCATATTGGGC & & HA & \\
\hline AHI B F ${ }^{a}$ & ATAGGCTACCATGCGAACAA & \multirow{2}{*}{$\begin{array}{c}944 \text { bp } \\
\text { (Ellis et al. 1997) }\end{array}$} & HA & \\
\hline AHI EII R ${ }^{a}$ & CTTAGTCCTGTAACCATCCT & & HA & \\
\hline $\mathrm{AH} 3 \mathrm{~B} \mathrm{~F}^{a}$ & AGCAAAGCTTTCAGCAACTG & \multirow{2}{*}{$\begin{array}{c}591 \mathrm{bp} \\
\text { (Ellis et al. 1997) }\end{array}$} & HA & \\
\hline AH3 CII R ${ }^{a}$ & GCTTCCATTTGGAGTGATGC & & HA & \\
\hline $\mathrm{BHA} \mathrm{B} \mathrm{F}^{a}$ & CATTTTGCAAATCTCAAAGC & $767 \mathrm{bp}$ & HA & \\
\hline $\mathrm{BHA} \mathrm{CII} \mathrm{R}^{a}$ & TGGAGGCAATCTGCTTCACC & (Ellis et al. 1997) & HA & \\
\hline $\mathrm{N} 1 \mathrm{~F}^{c}$ & ATGGGACAAGTGAAAATGTC & 928 bp & $\mathrm{N}$ & \multirow[t]{5}{*}{ hMPV } \\
\hline $\mathrm{N} 2 \mathrm{~F}^{b}$ & GAGTCTCAGTACACAATAA & (Mirazo et al. 2005) & $\mathrm{N}$ & \\
\hline $\mathrm{N} 3 \mathrm{R}^{b}$ & GCATTTCCGAGAACAACAC & & $\mathrm{N}$ & \\
\hline $\mathrm{S} 1 \mathrm{~F}^{a}$ & ACGGGTAGAGAAGAGCTGG & \multirow{2}{*}{$\begin{array}{c}616 \text { bp } \\
\text { (Samransamruajkit et al. 2006) }\end{array}$} & $\mathrm{N}$ & \\
\hline $\mathrm{S} 2 \mathrm{R}^{a}$ & GCAAAGTTGGGACAGTTGGC & & $\mathrm{N}$ & \\
\hline PIP1 F ${ }^{b}$ & CCTTAAATTCAGATATGTAT & \multirow{4}{*}{$\begin{array}{c}317 \text { bp } \\
\text { (Echevarría et al. 1998) }\end{array}$} & $\mathrm{HA} / \mathrm{NA}$ & \multirow[t]{12}{*}{ PIV 1,2 and 3} \\
\hline PIP1 $\mathbf{R}^{b}$ & GATAAATAATTATTGATACG & & $\mathrm{HA} / \mathrm{NA}$ & \\
\hline PIS $1 \mathrm{~F}^{a}$ & CCGGTAATTTCTCATACCTATG & & $\mathrm{HA} / \mathrm{NA}$ & \\
\hline PIS $1 \mathrm{R}^{a}$ & CTTTGGAGCGGAGTTGTTAAG & & HA/NA & \\
\hline PIP2 $F^{b}$ & AACAATCTGCTGCAGCATTT & \multirow{4}{*}{$\begin{array}{c}203 \text { bp } \\
\text { (Echevarría et al. 1998) }\end{array}$} & $\mathrm{HA} / \mathrm{NA}$ & \\
\hline PIP2 $\mathrm{R}^{b}$ & ATGTCAGACAATGGGCAAAT & & $\mathrm{HA} / \mathrm{NA}$ & \\
\hline PIS $2 \mathrm{~F}^{a}$ & CCATTTACCTAAGTGATGGAAT & & HA/NA & \\
\hline PIS $2 \mathrm{R}^{a}$ & GCCCTGTTGTATTTGGAAGAGA & & $\mathrm{HA} / \mathrm{NA}$ & \\
\hline PIP3 F ${ }^{b}$ & CTGTAAACTCAGACTTGGTA & \multirow{4}{*}{$\begin{array}{c}102 \text { bp } \\
\text { (Echevarría et al. 1998) }\end{array}$} & $\mathrm{HA} / \mathrm{NA}$ & \\
\hline PIP3 $\mathrm{R}^{b}$ & TTTAAGCCCTTGTCAACAAC & & $\mathrm{HA} / \mathrm{NA}$ & \\
\hline PIS $3 \mathrm{~F}^{a}$ & ACTCCCAAAGTTGATGAAAGAT & & $\mathrm{HA} / \mathrm{NA}$ & \\
\hline PIS $3 \mathrm{R}^{a}$ & TAAATCTTGTTGTTGAGATTG & & HA/NA & \\
\hline
\end{tabular}

$a$ : used in nested-PCR; $b$ : used in PCR; $c$ : used in complementary DNA synthesis; F: forward; HA: hemagglutinin; N: nucleocapsid protein; NA: neuraminidase; P: phosphoprotein; R: reverse; UTR: untranslated region. 
TABLE II

Distribution of cases by clinical diagnosis and infection agents

\begin{tabular}{|c|c|c|c|c|c|c|c|c|c|c|c|c|}
\hline \multirow[b]{3}{*}{ Illness } & \multirow[b]{3}{*}{ Clinical severity } & & & \multicolumn{6}{|c|}{ Co-infected } & \multirow{2}{*}{\multicolumn{2}{|c|}{ All co-infected }} & \multirow{3}{*}{$\frac{\text { Total }}{\mathrm{n} \text { (age) }}$} \\
\hline & & \multicolumn{2}{|c|}{ HRV alone } & \multicolumn{2}{|c|}{$\mathrm{HRV}+\mathrm{RSV}$} & \multicolumn{2}{|c|}{ HRV + hMPV } & \multicolumn{2}{|c|}{ HRV + PIV } & & & \\
\hline & & $\mathrm{n}$ & $\mathrm{Age}^{a}$ & $\mathrm{n}$ & $\operatorname{Age}^{a}$ & $\mathrm{n}$ & $\mathrm{Age}^{a}$ & $\mathrm{n}$ & $\mathrm{Age}^{a}$ & $\mathrm{n}$ & $\operatorname{Age}^{a}$ & \\
\hline \multirow[t]{3}{*}{ Bronchiolitis } & Mild & 8 & 1.5 & 3 & 3.0 & 2 & 5.0 & 1 & $1.0^{b}$ & 6 & 3.0 & $38(2.5)$ \\
\hline & Moderate & 7 & 3.0 & 5 & 1.0 & 1 & $6.0^{b}$ & 1 & $1.0^{b}$ & 7 & 1.0 & \\
\hline & Severe & 5 & 3.0 & 1 & $8.0^{b}$ & 1 & $2.0^{b}$ & 3 & 2.0 & 5 & 2.0 & \\
\hline \multirow[t]{3}{*}{ Pneumonia } & Pneumonia & 3 & 5.0 & 0 & 0.0 & 0 & 0.0 & 0 & 0.0 & 0 & 0.0 & $10(2.5)$ \\
\hline & Severe & 4 & 8.0 & 3 & 1.0 & 0 & 0.0 & 0 & 0.0 & 3 & 1.0 & \\
\hline & Very severe & 0 & 0.0 & 0 & 0.0 & 0 & 0.0 & 0 & 0.0 & 0 & 0.0 & \\
\hline \multirow[t]{3}{*}{ Other $^{c}$} & Mild & 19 & 12.0 & 7 & 16.0 & 2 & 27.5 & 1 & $2.0^{b}$ & 10 & 11.5 & $35(11.0)$ \\
\hline & Moderate & 5 & 8.0 & 0 & 0.0 & 0 & 0.0 & 0 & 0.0 & 0 & 0.0 & \\
\hline & Severe & 1 & $3.0^{b}$ & 0 & 0.0 & 0 & 0.0 & 0 & 0.0 & 0 & 0.0 & \\
\hline Total & & 52 & 5.0 & 19 & 2.0 & 6 & 6.5 & 6 & 1.5 & 31 & 2.0 & $83(4.0)$ \\
\hline
\end{tabular}

$a$ : median age in months; $b$ : child age in months; $c$ : includes acute bronchitis, sibilant bronchitis, tracheobronchitis and croup; hMPV: metapneumovirus; HRV: human rhinovirus; PIV: parainfluenzaviruses; RSV: respiratory syncytial virus.

Bronchiolitis was the most common clinical manifestation, accounting for 45.8\% (38/83) of cases, followed by LRTI (acute bronchitis, sibilant bronchitis, tracheobronchitis and croup) in $42.2 \%(35 / 83)$ of cases and pneumonia in $12 \%(10 / 83)$ of cases. An analysis of the severe cases of bronchiolitis, pneumonia and LRTI revealed no statistical differences in the frequency between single infection (HRV alone) and dual infection $(p>0.05)$. Also, no difference was observed between patients infected with a single virus who presented with moderate to severe illness compared to those with dual infection $(p>0.05)$ (Table II).

The median age of children with dual virus infection was two months, which was significantly different from the mean age of children infected with HRV alone (5.0 m.o. $)(p=0.0386)$. The median age of children co-infect-

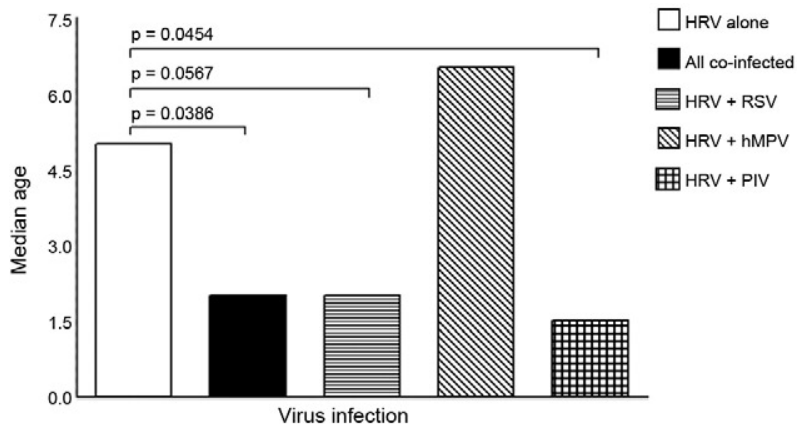

Fig. 2: median age, in months, of children younger than five years of age presenting lower respiratory tract illness who had human rhinovirus (HRV) infection or co-infection attended at a public hospital in Uberlândia, Minas Gerais, Brazil. hMPV: metapneumovirus; PIV: parainfluenza viruses; RSV: respiratory syncytial virus. ed with HRV and PIV (1.5 m.o.) was significantly lower than the median age of children infected with HRV only ( $p=0.0454)$. Additionally, younger children (2.0 m.o.) seemed to be more prone to co-infection with HRV and RSV than to suffer from a single HRV infection $(\mathrm{p}=0.0568)($ Fig. 2).

\section{DISCUSSION}

In this study, the rate of HRV co-infection with other respiratory viruses was found to be similar to rates in other countries (Calvo et al. 2007, Cilla et al. 2008). The high frequency of HRV co-infection with RSV has been observed previously (Papadopoulos et al. 2002, Paranhos-Baccalà et al. 2008, Richard et al. 2008, Gerna et al. 2009). In our region, the high prevalence of HRV and RSV co-infection may be related to seasonal trends (Costa et al. 2006, Oliveira et al. 2008); HRV and RSV infections peak concurrently.

Previous reports suggested that co-infection with viral respiratory diseases may result in a more severe clinical manifestation than infection with only one virus (Aberle et al. 2005, Cilla et al. 2008, van der Zalm et al. 2009). Richard et al. (2008) suggested that dual infection is a risk factor for more severe illness, which is independent of the host's condition. Moreover, HRV-RSV coinfections have been associated with a higher likelihood of presenting with severe clinical syndromes than infection with HRV alone (Aberle et al. 2005). However, our results show that LRTI associated with viral co-infection does not result in a higher incidence of severe syndromes compared to infection with HRV alone. Other groups have reported similar results (Williams et al. 2004, Choi et al. 2006, Calvo et al. 2007, Louie et al. 2009).

In contrast to previous reports (Calvo et al. 2007, 2008, Cheuk et al. 2007, Bonzel et al. 2008), we observed that HRV-PIV co-infection (median of 1.5 m.o.) was more 
common in younger children. According to van der Zalm (2009), younger children may be more prone to co-infection because they have a less developed immune system.

In conclusion, our results indicate that HRV co-infection with a second respiratory virus is not responsible for more severe LRTI in young children.

\section{ACKNOWLEDGEMENTS}

To the laboratories of Immunology, Parasitology, Molecular Biology, Physiology and Genetics, UFU, for allowing us to use their facilities and the health care professionals of the Clinics Hospital of Uberlândia for the screening of patients.

\section{REFERENCES}

Aberle JH, Aberle SW, Pracher E, Hutter HP, Kundi M, PopowKraupp T 2005. Single versus dual respiratory virus infections in hospitalized infants: impact on clinical course of disease and interferon-gamma response. Pediatr Infect Dis J 24: 605-610.

Arruda E, Hayden FG 1993. Detection of human rhinovirus RNA in nasal washings by PCR. Mol Cell Probes 7: 373-379.

Bonzel L, Tenenbaum T, Schroten H, Schildgen O, Schweitzer-Krantz $\mathrm{S}$, Adams O 2008. Frequent detection of viral coinfection in children hospitalized with acute respiratory tract infection using a realtime polymerase chain reaction. Pediatr Infect Dis J 27: 589-594.

Calvo C, García-García ML, Blanco C, Pozo F, Flecha IC, Pérez-Breña $P$ 2007. Role of rhinovirus in hospitalized infants with respiratory tract infections in Spain. Pediatr Infect Dis J 26: 904-908.

Calvo C, García-García ML, Blanco C, Vázquez MC, Frías ME, PérezBreña P, Casas I 2008. Multiple simultaneous viral infections in infants with acute respiratory tract infections in Spain. J Clin Virol 42: $268-272$.

Carneiro BM, Yokosawa J, Arbiza J, Costa LF, Mirazo S, Nepomuceno LL, Oliveira TF, Goulart LR, Vieira CU, Freitas GR, Paula NT, Queiróz DA 2009. Detection of all four human metapneumovirus subtypes in nasopharyngeal specimens from children with respiratory disease in Uberlândia, Brazil. J Med Virol 81: 1814-1818.

Cheuk DK, Tang IW, Chan KH, Woo PC, Peiris MJ, Chiu SS 2007. Rhinovirus infection in hospitalized children in Hong Kong: a prospective study. Pediatr Infect Dis J 26: 995-1000.

Choi EH, Lee HJ, Kim SJ, Eun BW, Kim NH, Lee JA, Lee JH, Song EK, Kim SH, Park JY, Sung JY 2006. The association of newly identified respiratory viruses with lower respiratory tract infections in Korean children, 2000-2005. Clin Infect Dis 43: 585-592.

Cilla G, Oñate E, Perez-Yarza EG, Montes M, Vicente D, PerezTrallero E 2008. Viruses in community-acquired pneumonia in children aged less than 3 years old: high rate of viral coinfection. J Med Virol 80: 1843-1849.

Costa LF, Yokosawa J, Mantese OC, Oliveira TFM, Silveira HL, Nepomuceno LL, Moreira LS, Dyonisio G, Rossi LMG, Oliveira RC, Ribeiro LZG, Queiróz DAO 2006. Respiratory viruses in children younger than five years old with acute respiratory disease from 2001 to 2004 in Uberlândia, MG, Brazil. Mem Inst Oswaldo Cruz 101: 301-306.

De Boeck K, Van der Aa N, Van Lierde S, Corbeel L, Eeckels R 1997. Respiratory syncytial virus bronchiolitis: a double-blind dexamethasone efficacy study. J Pediatr 131: 919-921.

Dreschers S, Dumitru CA, Adams C, Gulbins E 2007. The cold case: are rhinoviruses perfectly adapted pathogens? Cell Mol Life Sci 64: 181-191.

Drews AL, Atmar RL, Glezen WP, Baxter BD, Piedra PA, Greenberg SB 1997. Dual respiratory virus infections. Clin Infect Dis 25: 1421-1429.
Echevarría JE, Erdman DD, Swierkosz EM, Holloway BP, Anderson LJ 1998. Simultaneous detection and identification of human parainfluenza viruses 1,2, and 3 from clinical samples by multiplex PCR. J Clin Microbiol 36: 1388-1391.

Ellis JS, Fleming DM, Zambon MC 1997. Multiplex reverse transcription-PCR for surveillance of influenza A and B viruses in England and Wales in 1995 and 1996. J Clin Microbiol 35: 2076-2082.

Gern JE, Busse WW 1999. Association of rhinovirus infections with asthma. Clin Microbiol Rev 12: 9-18.

Gerna G, Piralla A, Rovida F, Rognoni V, Marchi A, Locatelli F, Meloni F 2009. Correlation of rhinovirus load in the respiratory tract and clinical symptoms in hospitalized immunocompetent and immunocompromised patients. J Med Virol 81: 1498-1507.

Glezen WP, Greenberg SB, Atmar RL, Piedra PA, Couch RB 2000. Impact of respiratory virus infections on persons with chronic underlying conditions. JAMA 283: 499-505.

Jacques J, Bouscambert-Duchamp M, Moret H, Carquin J, Brodard V, Lina B, Motte J, Andreoletti L 2006. Association of respiratory picornaviruses with acute bronchiolitis in French infants. J Clin Virol 35: 463-466.

Kelly JT, Busse WW 2008. Host immune responses to rhinovirus: mechanisms in asthma. J Allergy Clin Immunol 122: 671-682.

Kim JO, Hodinka RL 1998. Serious respiratory illness associated with rhinovirus infection in a pediatric population. Clin Diagn Virol 10: 57-65.

Kirchberger S, Majdic O, Stock1 J 2007. Modulation of the immune system by human rhinoviruses. Int Arch Allergy Immunol 142: 1-10.

Kistler AL, Webster DR, Rouskin S, Magrini V, Credle JJ, Schnurr DP, Boushey HA, Mardis ER, Li H, DeRisi JL 2007. Genomewide diversity and selective pressure in the human rhinovirus. Virol J 4: 40

Lau SK, Yip CC, Tsoi HW, Lee RA, So LY, Lau YL, Chan KH, Woo PC, Yuen KY 2007. Clinical features and complete genome characterization of a distinct human rhinovirus (HRV) genetic cluster, probably representing a previously undetected HRV species, HRV-C, associated with acute respiratory illness in children. J Clin Microbiol 45: 3655-3664.

Louie JK, Roy-Burman A, Guardia-Labar L, Boston EJ, Kiang D, Padilla T, Yagi S, Messenger S, Petru AM, Glaser CA, Schnurr DP 2009. Rhinovirus associated with severe lower respiratory tract infections in children. Pediatr Infect Dis J 28: 337-339.

Mackay IM 2008. Human rhinoviruses: the cold wars resume. J Clin Virol 42: 297-320.

Malcolm E, Arruda E, Hayden FG, Kaiser L 2001. Clinical features of patients with acute respiratory illness and rhinovirus in their bronchoalveolar lavages. J Clin Virol 21: 9-16.

Manoha C, Espinosa S, Aho SL, Huet F, Pothier P 2007. Epidemiological and clinical features of hMPV, RSV and RVs infections in young children. J Clin Virol 38: 221-226.

Marguet C, Lubrano M, Gueudin M, Le Roux P, Deschildre A, Forget C, Couderc L, Siret D, Donnou MD, Bubenheim M, Vabret A, Freymuth F 2009. In very young infants severity of acute bronchiolitis depends on carried viruses. PLoS One 4: e4596.

Midulla F, Scagnolari C, Bonci E, Pierangeli A, Antonelli G, De Angelis D, Berardi R, Moretti C 2010. Respiratory syncytial virus, human bocavirus and rhinovirus bronchiolitis in infants. Arch Dis Child 95: 35-41.

Miller EK, Lu X, Erdman DD, Poehling KA, Zhu Y, Griffin MR, Hartert TV, Anderson LJ, Weinberg GA, Hall CB, Iwane MK, Edwards KM 2007. Rhinovirus-associated hospitalizations in young children. J Infect Dis 195: 773-781. 
Mirazo S, Ruchansky D, Blanc A, Arbiza J 2005. Serologic evidence of human metapneumovirus circulation in Uruguay. Mem Inst Oswaldo Cruz 100: 715-718.

Oliveira TFM, Freitas GRO, Ribeiro LZG, Yokosawa J, Siqueira MM, Portes SAR, Silveira HL, Calegari T, Costa LF, Mantese OC, Queiróz DAO 2008. Prevalence and clinical aspects of respiratory syncytial virus A and B groups in children seen at Hospital de Clínicas of Uberlândia, MG, Brazil. Mem Inst Oswaldo Cruz 103: 417-422.

Palmenberg AC, Spiro D, Kuzmickas R, Wang S, Djikeng A, Rathe JA, Fraser-Liggett CM, Liggett SB 2009. Sequencing and analyses of all known human rhinovirus genomes reveal structure and evolution. Science 324: 55-59.

Papadopoulos NG, Moustaki M, Tsolia M, Bossios A, Astra E, Prezerakou A, Gourgiotis D, Kafetzis D 2002. Association of rhinovirus infection with increased disease severity in acute bronchiolitis. Am J Respir Crit Care Med 165: 1285-1289.

Paranhos-Baccalà G, Komurian-Pradel F, Richard N, Vernet G, Lina B, Floret D 2008. Mixed respiratory virus infections. J Clin Virol 43: 407-410.

Richard N, Komurian-Pradel F, Javouhey E, Perret M, Rajoharison A, Bagnaud A, Billaud G, Vernet G, Lina B, Floret D, ParanhosBaccalà $G$ 2008. The impact of dual viral infection in infants admitted to a pediatric intensive care unit associated with severe bronchiolitis. Pediatr Infect Dis J 27: 213-217.
Samransamruajkit R, Thanasugarn W, Prapphal N, Theamboonlers A, Poovorawan Y 2006. Human metapneumovirus in infants and young children in Thailand with lower respiratory tract infections; molecular characteristics and clinical presentations. $J$ Infect 52: 254-263.

Stockton J, Ellis JS, Saville M, Clewley JP, Zambon MC 1998. Multiplex PCR for typing and subtyping influenza and respiratory syncytial viruses. J Clin Microbiol 36: 2990-2995.

Taussig LM, Castro O, Beaudry PH, Fox WW, Bureau M 1975. Treatment of laryngotracheobronchitis (croup). Use of intermittent positive-pressure breathing and racemic epinephrine. Am J Dis Child 129: 790-793.

van der Zalm MM, van Ewijk BE, Wilbrink B, Uiterwaal CS, Wolfs TF, van der Ent CK 2009. Respiratory pathogens in children with and without respiratory symptoms. J Pediatr 154: 396-400.

WHO - World Health Organization 2005. [Database on the internet]. Pocket book of hospital care for children. Guidelines for the management of common illnesses with limited resources. Available from: www.who.int/child adolescent health/ documents/9241546700/en/.

Williams JV, Harris PA, Tollefson SJ, Halburnt-Rush LL, Pingsterhaus JM, Edwards KM, Wright PF, Crowe JE Jr 2004. Human metapneumovirus and lower respiratory tract disease in otherwise healthy infants and children. N Engl J Med 350: 443-450. 